\title{
How have Zambian businesses reacted to the HIV epidemic?
}

Rachel Baggaley, Peter Godfrey-Faussett, Roland Msiska, Diane Chilangwa, Eusabio Chitu, John Porter, Michael Kelly

\begin{abstract}
Objectives-To evaluate the impact of HIV on businesses in Zambia and to assess attitudes towards HIV and HIV education in the workplace.

Methods-The personnel managers of 33 companies with a total workforce of 10204 in Lusaka and in towns in the Copperbelt were visited by two members of the study team. The study was discussed and a questionnaire about the impact of HIV on their company was explained and left for completion from company records.
\end{abstract}

Results-All 33 questionnaires were returned. HIV was recognised to be a problem by 30 companies questioned. Seven said that it had affected recruitment and 11 production. 23 companies carried out pre-employment medicals. 17 companies demanded that some or all of their employees had an HIV test before employment. Nine companies were sure that a positive HIV test would prevent employment, 15 were unsure saying that there was no particular company policy. Two companies had recently changed their policy and had stopped discriminating against those with HIV. 12 companies had some HIV educational material available for their employees and five had someone (or an organisation that they used) to whom they could refer employees for HIV information and advice. Condoms were provided free to staff by five of the companies. All thought that HIV education in the workplace was an appropriate intervention. Mortality data showed a sevenfold increase in the crude mortality from $0 \cdot 25-1.8$ per 100 personyears from 1987-93, and an increasing trend in reported deaths from AIDS and HIV related conditions.

Conclusions-HIV is having an important impact in the workplace in urban Zambia. Although many companies insist on pre-employment medicals, often including HIV testing, few have developed policies relating to test results. Some companies have instituted HIV education but there is a demand for this service to be available more widely. There has been a striking increase in mortalities in this working population, which seems likely to be related to HIV, although the cause of most deaths was not recorded.
(Occup Environ Med 1995;52:565-569)

Keywords: HIV; Zambia; businesses

Zambia is one of the countries in Africa most affected by the epidemic of human immunodeficiency virus (HIV). Seroprevalence studies of blood donors and of women attending antenatal clinics have shown rates of infection between $11 \%$ and $30 \% .^{1}$ Many people in Zambia have a friend or relative who has died of AIDS. Although many diseases in Africa affect principally the old and young age groups and the least privileged groups in society, HIV is unusual in infecting young adults, who are the breadwinners of the community. Deaths in this section of society are likely to have a significant effect on the economy of individual family units and if widespread are bound to weaken the nation's economic position. ${ }^{2}$

Kara Counselling and Training Trust (KCTT) a Zambian non-governmental organisation has been offering HIV education through an outreach programme to local companies since 1990. Education programmes are carried out by 10 trained HIV educators who live openly and positively with HIV and are members of the "Positive and Living Squad" (PALS). We therefore decided to study the impact of HIV on businesses in Zambia, as reported by senior management staff.

\section{Methods}

Thirty three companies were visited by two members of the study team between June and August 1993. Twenty five were based in Lusaka, the capital (population 982000 , 1990 census) and eight were based in the Copperbelt, an area with several large towns in the mining region of the country (total population 1200000,1990 census). Zambia has a total population of about eight and a half million with 300000 formally employed (registered for income tax purposes), 75000 in Lusaka and 100000 in the Copperbelt. A further one and a half million people earn an income through activities such as trading and casual labour. A wide range of companies in banking, accountancy services, vehicle sales and assembly, food and drink manufacture, and farming were questioned. The companies were not selected randomly. Some had approached KCTT to ask for HIV education programmes to be initiated whereas others had been approached by KCTT through an 
Table 1 Size of companies

\begin{tabular}{lc}
\hline Employees & Companies \\
\hline$<100$ & 12 \\
$101-200$ & 10 \\
$201-500$ & 7 \\
$>500$ & 4 \\
\hline
\end{tabular}

informal network of contacts in the business communities of Lusaka and the Copperbelt.

The purpose of the study was explained and a questionnaire was left for completion from the company records by the personnel manager. The questionnaire was collected after one week and difficulties in filling in any of the sections were clarified.

The questionnaire covered details of the age range and sex of employees and staff turnover (estimated by the personnel manager); health care provision and pre-employment medical practices, including whether or not HIV testing was performed, sickness benefits, company policy, and attitudes towards HIV including provision of education and condoms. Overall mortality and cause specific mortality for tuberculosis, accidents, cancer, heart disease, diarrhoea, AIDS, and stroke were collected from the company records. Personnel managers were asked about their perceived effects of $\mathrm{HIV}$ on productivity and recruitment. We asked for copies of the company funeral policy, and its estimated cost, and whether any changes had been made to this. Also personnel managers were invited to comment on what measures were being taken to reduce the impact of $\mathrm{HIV}$ and to suggest additional measures.

Data were entered into a database (epi-info 5, CDC Atlanta and WHO, Geneva) and proportions that gave each possible answer to each question were calculated. Mortality and morbidity trends over the past six years (1987-93) were analysed with the $\chi^{2}$ test for trend (epi-info 5). Mortalities were calculated by dividing the number of deaths in each year by the total number of employees at each year's end.

\section{Results}

Thirty three companies filled in questionnaires. All questionnaires were returned fully completed except one company that could not find its mortality records. The total number of employees in 1993 was 10204 (79\% men and $21 \%$ women); the range for individual companies was 19 to 1836 (table 1). The total number of employees did not vary significantly over the study period.

Most of the companies had a workforce aged between 18-55 years. Four companies had employees over 55 and one over 65 .

\section{HIV-DOES IT HAVE AN EFFECT ON THE} COMPANY?

Table 2 shows that 30 personnel managers thought that HIV had affected their company in some way. It was felt that HIV had affected productivity in 11 and recruitment in seven of the companies. The main worry from personnel managers was the loss of trained and highly skilled staff who were difficult to replace and who had often been time consuming and expensive to train. Although the other 12 companies said that HIV had not directly affected productivity or recruitment, it had an effect on their company in other ways. Two companies said that they were aware of deaths in their workforce that they (the personnel managers) thought were due to HIV but were being attributed to witchcraft. One personnel manager, whose company was involved in car assembly, was worried about the occupational hazards of HIV and wanted help with devising a policy to prevent transmission through workplace accidents.

Seven personnel managers had made changes to their policy about leave for funerals because of the time being lost by staff attending an increasing number of funerals. Employees were now made to take days off for funerals as holiday leave rather than being allowed the time off.

All companies gave funeral grants or paid for funeral expenses (table 3). We estimated that the cost to a company of a funeral was the

Table 2 How has HIV affected your business?

\begin{tabular}{|c|c|c|}
\hline & No & Example \\
\hline Not at all & 3 & $\begin{array}{l}\text { "We are a small firm and haven't lost anyone yet from HIV so it's not a problem yet, } \\
\text { but it is only a matter of time." }\end{array}$ \\
\hline Productivity & 11 & $\begin{array}{l}\text { "We have to pay wages to non-productive employees and death benefits to surviving } \\
\text { spouses with a death rate at higher than we planned." } \\
\text { "We now have to employ extra staff just to cover the leave for funerals." } \\
\text { "We have lost specialist staff and additional costs have been incurred in retraining. } \\
\text { We have had to take on extra trainees in specialist areas because we know that } \\
\text { some will be lost." }\end{array}$ \\
\hline $\begin{array}{l}\text { Recruitment } \\
\text { and training }\end{array}$ & 7 & $\begin{array}{l}\text { "We find it difficult to replace key management staff." } \\
\text { "It's not so important if we lose a cleaner or one of the clerical staff but we have lost } \\
\text { one of our chief accountants, and one of last year's graduate intake has just died } \\
\text { after only } 9 \text { months with us and we had spent a lot of time and money training } \\
\text { him. This is why we want to introduce testing for all new employees." } \\
\text { "We have a loss of trained personnel which is difficult to replace and large ex gratia } \\
\text { payments which the company has to pay to survivors." } \\
\text { "We have lost many trained staff which are difficult to replace and train." }\end{array}$ \\
\hline $\begin{array}{l}\text { Other: } \\
\text { Humanitarian }\end{array}$ & 12 & $\begin{array}{l}\text { "It's not just the problem of replacing good staff who are sick or die, it is a } \\
\text { humanitarian thing. This is why we support the idea of HIV education because we } \\
\text { don't want to see any more of our colleagues die." } \\
\text { "It causes a general depression. I think who is going to be next. It is not nice to see } \\
\text { colleagues you have worked with for a long time getting sicker and sicker." }\end{array}$ \\
\hline General worry & & $\begin{array}{l}\text { "It hasn't effected our production because things have been quite slack recently and } \\
\text { there are always people who are out of work so there are no problems with getting } \\
\text { more labour. But it is something that worries a lot of us." }\end{array}$ \\
\hline Traditional beliefs & & $\begin{array}{l}\text { "AIDS" is there amongst the farm workers. There have been accusations of } \\
\text { witchcraft amongst some of the labourers- that is why we have been getting so } \\
\text { worried. We want to get some education in to let them know about HIV." }\end{array}$ \\
\hline Occupational health worries & & $\begin{array}{l}\text { "You do worry about what could happen if we had an accident at work, we use a lot of } \\
\text { machines and people could lose blood and AIDS could be spread that way. So I } \\
\text { take anyone sickly off that sort of work." }\end{array}$ \\
\hline
\end{tabular}


Table 3 Example of funeral assistance given to an employee after the death of his wife in one of the companies questioned in Fuly 1993

\begin{tabular}{lcc}
\hline & Kwacha & $\begin{array}{l}\text { Approximate } \\
\text { sterling } \\
\text { equivalent }\end{array}$ \\
\hline Mealie meal $(150 \mathrm{~kg})$ & 21000 & 21 \\
Chicken meat $(40 \mathrm{~kg})$ & 20000 & 20 \\
Salt $(5 \mathrm{~kg})$ & 1550 & 1.55 \\
Cooking oil (10 1) & 12000 & 12 \\
Beer (3 crates) & 6000 & 6 \\
Minerals (3 crates) & 4000 & 4 \\
Firewood or 6000 in lieu & 6000 & 6 \\
K20 000 Funeral grant & 20000 & 20 \\
Coffin & 55000 & 55 \\
Transport for mourners & 25000 & 25 \\
Total & 170550 & 170.55 \\
\hline
\end{tabular}

equivalent of $£ 170$, the monthly wage for the employee at that time being $£ 60$. Not all companies were as generous and seven had reduced their funeral benefits to a standard funeral grant, payment for a coffin, and provision of transport. Five companies reported that they had changed their funeral benefits to cover only close relatives, such as the spouse and children of the employee, whereas they had previously provided support for the more extended family.

\section{HIV INFECTION AND MORTALITY AMONGST EMPLOYEES}

The data on mortality have been published previously. ${ }^{3}$ Nine personnel managers said that they knew of employees who were infected with HIV, 22 did not know of any HIV positive employees, many commenting that this was not something that would be revealed to the personnel department. As HIV carries such a stigma, employees are usually very reluctant to discuss their ill health, despite the fact that it may be of benefit to them. Adequate provisions for sick leave or retirement on medical grounds can often be made if the personnel manager is aware of an employee's medical problems. Many of the personnel managers said that they suspected that a colleague was HIV positive because he had become thin or their partner, or baby, had died recently; but they said that they could not say this was HIV. Only two said they had no staff who were HIV seropositive.
The company without mortality statistics was one of the smaller companies with 40 employees. Among the remaining 32 companies, the crude death rate for this population increased sequentially ( $P<0.001, \chi^{2}$ test for trend) from $0 \cdot 25 / 100$ person-years (95\% CI $0 \cdot 15-0.35$ ) in 1987 to $1.83 / 100$ person years (95\% CI $1.57-2 \cdot 09$ ) in 1993. There were 26 deaths among 10319 employees in 1987 and 187 deaths among 10204 in 1993 (table 4).

Most deaths were recorded as due to unknown causes although deaths from tuberculosis, diarrhoea and AIDS were recorded with increasing frequency whereas there was no significant trend for deaths due to accidents, heart disease, stroke, or cancer.

\section{PRE-EMPLOYMENT HIV TESTING}

Twenty three companies questioned carried out medicals on some or all of their employees before employment. Eight companies carried out HIV tests on all employees before employment. A further nine asked some of their employees to have HIV tests before employment. These were usually more skilled employees or employees being sent for further training. Two companies had previously carried out HIV testing on all new recruits but had changed their policy. Three personnel managers said that they thought that their company's policy of pre-employment testing was putting potential recruits off applying for jobs. Only seven firms were certain that a positive test would not prevent employment. Fifteen firms were unsure, and nine said that a positive test would prevent a person being employed. Two firms said that they had previously discriminated against new employees who were found to be HIV positive, but their companies had recently changed this policy.

\section{HIV EDUCATION}

Twelve companies had had some form of HIV education at the workplace. This was usually in the form of posters in the cloakrooms and some written material available to the workforce rather than a formal education programme. Five companies had HIV advice and counselling available. This was either through the company (in one case) or by referral to an HIV counselling service. Five supplied

Table 4 Crude annual mortality and causes of death in employees of 33 Zambian businesses from 1987 to 1993

\begin{tabular}{|c|c|c|c|c|c|c|c|c|}
\hline & 1987 & 1988 & 1989 & 1990 & 1991 & 1992 & $1993 \dagger$ & $P$ value ${ }^{\star}$ \\
\hline $\begin{array}{l}\text { Total number } \\
\text { of employees }\end{array}$ & 10319 & 10228 & 10199 & 10296 & 10145 & 10168 & 10204 & \\
\hline $\begin{array}{l}\text { Total number } \\
\text { of deaths }\end{array}$ & 26 & 49 & 52 & 84 & 10116 & 160 & 187 & \\
\hline $\begin{array}{l}\text { Crude annual } \\
\text { mortality (\%) }\end{array}$ & $0 \cdot 25$ & 0.48 & 0.51 & 0.82 & $1 \cdot 14$ & $1 \cdot 57$ & $1 \cdot 83$ & $<0.001$ \\
\hline Tuberculosis & 6 & 2 & 3 & 9 & 11 & 14 & 18 & $<0.01$ \\
\hline Accidents & 2 & 7 & 4 & 2 & 0 & 2 & 0 & $>0.05$ \\
\hline Heart disease & 2 & 0 & 0 & 0 & 0 & 2 & 2 & $>0.05$ \\
\hline Cancer & 1 & 0 & 0 & 1 & 0 & 0 & 0 & $>0.05$ \\
\hline Diarrhoea & 0 & 3 & 0 & 2 & 3 & 6 & 5 & $<0.05$ \\
\hline AIDS & 1 & 4 & 6 & 11 & 14 & 24 & 36 & $<0.001$ \\
\hline Stroke & 0 & 0 & 0 & 0 & 1 & 0 & 0 & $>0.05$ \\
\hline Unknown & 14 & 33 & 39 & 59 & 87 & 112 & 126 & $<0.001$ \\
\hline
\end{tabular}

$\star \chi^{2}$ test for trend.

The values for 1993 were predicted. The number of deaths observed was divided by the number of months before the questionnaire was completed and multiplied by 12 .

Figures for causes of deaths are numbers of deaths recorded whereas mortality is recorded as a rate (\%/y). 
condoms free to their employees. All recognised the importance of HIV education and thought that the workplace was an appropriate place for this. All expressed an interest in having further HIV education for their workforce.

\section{Discussion}

The HIV issue is important to most of the companies questioned. It affects productivity, recruitment, and company morale. As unemployment is common in Zambia, replacement of lost manual labour is easy. On the other hand, there are many fewer skilled and professional workers, so the recruitment and loss of trained personnel is more critical to companies.

Although many of the companies insist on pre-employment medicals, often including HIV testing, few have developed policies relating to test results and some companies have noticed potential recruits declining employment when they discover that it will entail being tested.

The companies in the study were either approached by the study team or contacted KCTT because they wanted to know more about HIV in the workplace so it is not surprising that they all thought that the workplace was an appropriate place for HIV education. All companies in the study went on to have HIV workplace education programmes and these involve commitment from the company particularly in terms of staff time.

Much of the data presented are reported data, and comments from the personnel managers may be exaggerated to please the study team, especially when commenting on the effects of HIV on their businesses.

Although considerable data exist on patterns of childhood mortality in developing countries, much less is known about adult deaths. Many countries in the developing world do not have vital registration systems and census data are only collected infrequently. Murray and colleagues ${ }^{4}$ have estimated overall mortality between the ages of 15 and 60 to be about $23.5 \%$ in the developing world. An estimation of the average annual mortality in this age group should therefore be around 0.5 per 100 person-years.

The crude death rate amongst employees of the companies questioned rose from 0.25 to 1.8 per 100 person-years over the study period, a sevenfold increase. All the companies except one had mortality statistics for their companies. These records are likely to be accurate because employees who die have substantial funeral benefits in Zambia. For most of the companies questioned these included not only the provision of money to pay for a coffin, food and drinks for the funeral guests, but use of company transport to take relatives and the coffin to the cemetery. It is possible that some employees might have retired early due to ill health and so not appeared in the mortality figures when they died. The normal employment practices in
Zambia are generous to staff and allow employees to remain on sick leave for prolonged periods, so we think that few deaths will have been missed. Similar figures were found by Buve and colleagues, ${ }^{5}$ who reported that the mortality in female nurses from two hospitals in Zambia rose from 0.2 per 100 person-years (95\% CI $0.005-1 \cdot 1)$ between $1980-85$ to $2 \cdot 7$ per 100 person-years $(95 \% \mathrm{CI}$ 1.55-4.27) between 1989-91. Our data, collected from a much larger population fall well within the $95 \%$ CIs of that study.

This increase in crude mortality cannot be definitely attributed to HIV as most companies do not generally record cause of death. There was an increase in reporting of death from HIV, diarrhoea, and tuberculosis. Both tuberculosis ${ }^{6}$ and diarrhoea ${ }^{7}$ are strongly associated with HIV infection in Africa. Testing of HIV has not been widely available in Zambia and a great stigma still exists. Deaths from HIV are seldom recorded, even in official statistics, due to the reluctance of both doctors and the deceased's relatives to acknowledge publicly that HIV was the cause of death. Deaths attributed to tuberculosis or diarrhoea may therefore also have been due to HIV.

As the businesses were not selected randomly, there may be a bias in the sample, as those companies who are worried about HIV, or are aware of employees being affected by HIV are more likely to approach KCTT. Eight companies approached KCTT and the remaining 25 were contacted by KCTT as part of the outreach programme. KCTT is gradually trying to contact as many businesses as possible to offer them workplace education on HIV and the companies selected were the ones that KCTT contacted during the study period. Thus, while the companies approached by KCTT were not a random sample, they were not chosen because they were thought to be in any way at high risk. Furthermore, the size of the population sampled means that the rising death rate is important, even if it may not be able to be generalised to all Zambian industries.

Unemployment is a major problem in Zambia. The study population therefore does not represent those with least income and worst nutrition. It is unlikely that the increase in death rate found is due to poverty or malnutrition. ${ }^{8}$

The increase is sufficiently striking to make it unlikely that changes in the demography of the study population could account for it. None of the managers interviewed commented on such changes. Managers in some of the larger companies had noticed a rising mortality among their own workforces but the aggregation of a range within different businesses provides strong evidence that death is occurring increasingly frequently among Zambian employees.

This survey of 33 businesses with a total population of more than 10000 has shown that HIV has made an impact not only on mortality but on many aspects of company policy. It also highlights the needs of companies. Outreach education may help businesses 
to cope more effectively with the HIV epidemic, make humane and workable policies on HIV testing for employees and give their workforces education to reduce HIV transmission and the stigma that hampers preventive measures. We are currently studying the effect of outreach education on employees' behaviour and attitudes to HIV.

We acknowledge gratefully the help of Boniface Moonze and Janet Bennett (data entry); Maria Ouigley (statistical advice); and Eric van Praag and Keith McAdam for their helpful comments. The study was funded by the Enid Linder Foundation.

1 Nkowane BM. Prevalence and incidence of HIV infection in Africa: a review of data published in 1990. AIDS 1991;5(suppl 1):S7-15.
2 Cross $\mathrm{S}$, Whiteside A, eds. Facing up to AIDS. London: Macmillan 1993.

3 Baggaley R, Godfrey-Faussett P, Msiska R, Chilangura D, Chitu E, Porter J, Kelly M. Impact of HIV on Zambian businesses. BMF 1994;309:1549-50.

4 Murray CJL, Yang G, Qiao X. Adult mortality: levels, patterns and causes. In: Feachem RGA, Kjellstrom T, Murray CJL, Over M, Phillips MA, eds. The health of adults in the developing world New York: Oxford University Press, 1992;23-111.

5 Buve A, Foster SD, Mbwili C, Mungo E, Tollenare N, Zeko M. Mortality among female nurses in the face of the AIDS epidemic: a pilot study conducted in two hosthe AIDS epidemic: a pilot study conducted in two hospitals in the

6 Elliot A, Luo N, Tembo G, Halwiindi B, Steenbergen G, Machiels L, et al. The impact of HIV on tuberculosis in Zambia: a cross sectional study. $B M F$ 1990;301:412-5.

7 Piot P, Kapita BM, Ngugi EN, Mann JM, Colebunders R, Wabitsch R. AIDS in Africa: a manual for physicians. Geneva: World Health Organisation, 1992.

8 Hodgkinson N. The plague that never was. The Sunday Times London 3 October 1993.

\section{Instructions to authors}

Three copies of all submissions should be sent to: The Editor, Occupational and Environmental Medicine, BMJ Publishing Group, BMA House, Tavistock Square, London WC1H 9JR, UK. All authors should sign the covering letter as evidence of consent to publication. Papers reporting results of studies on human subjects must be accompanied by a statement that the subjects gave written, informed consent and by evidence of approval from the appropriate ethics committee. These papers should conform to the principles outlined in the Declaration of Helsinki (BMF 1964; ii:177).
If requested, authors shall produce the data on which the manuscript is based, for examination by the Editor.

Authors are asked to submit with their manuscript the names and addresses of three people who they consider would be suitable independent reviewers. They will not necessarily be approached to review the paper.

Papers should include a structured abstract of not more than 300 words, under headings of Objectives, Methods, Results, and Conclusions. Please include up to three keywords or key terms to assist with indexing. 